\title{
MANAJEMEN LINGKUNGAN KESEHATAN PERKOTAAN
}

\author{
Meuthia Geumala ${ }^{1}$, Agung Putri Harsa Satya Nugraha ${ }^{2}$, Yanna Eka Pratiwi ${ }^{3}$ \\ Fakultas Teknik $^{1}$, Kesehatan $^{2}$, Ekonomi $^{3}$ \\ Universitas Merdeka Surabaya \\ E-mail: gmeuthia@gmail.com
}

\begin{abstract}
ABSTRAK
Manajemen Kesehatan Lingkungan adalah suatu seni yang melaksanakan dan mengatur system dari bagian kesehatan masyarakat untuk menopang keseimbangan ekologis antara manusia dan lingkungannya (biotic dan abiotik) guna tercapainya kualitas hidup manusia yang sehat dan bahagia. Fungsi manajemen kesehatan lingkungan terdiri dari Fungsi perencanaan, Fungsi penggerakan dan pelaksanaan, Fungsi pengorganisasian dan Fungsi pengarahan dan pengawasan. Peran manajemen dalam kesehatan lingkungan adalah Pengelolaan lingkungan mempunyai dua dimensi yaitu "keterpaduan" dan "konflik". Idealnya, berbagai instrumen pengelolaan lingkungan dapat dirumuskan secara terpadu sehingga dapat mengakomodasi berbagai kelompok kepentingan. Dalam prakteknya, pengelolaan lingkungan tidak dapat dilepaskan dari konflik. Oleh karenanya para pengelola lingkungan harus mempunyai kapasitas untuk mengelola konflik dari berbagai kepentingan yang saling bertentangan.
\end{abstract}

Kata Kunci: Kesehatan Lingkungan, Perkotaan dan Manajemen Lingkungan.

\section{PENDAHULUAN}

Terrestrial environment is a stretch of the earth's surface which is the unity of space with energy, materials of various types of biomass and living creatures and man with all his behavior (Mahrus, Wicaksono, Cholil, \& Wiwoho, 2017). Masalah kesehatan merupakan salah satu faktor yang berperan penting dalam mewujudkan sumber daya manusia yang berkualitas. Melalui pembangunan di bidang kesehatan diharapkan akan semakin meningkatkan tingkat kesehatan masyarakat dan pelayanan kesehatan dapat dirasakan oleh semua lapisan masyarakat secara memadai (Dinas Kesehatan, 2007).

Masyarakat merupakan salah satu unsur utama dalam berdirinya suatu negara. Negara yang makmur, merupakan tanda bahwa negara tersebut memiliki masyarakat yang juga makmur. Kemakmuran ini didukung oleh banyak faktor. Salah satunya adalah kesehatan lingkungan masyarakat di suatu negara tersebut.

Kesehatan lingkungan adalah cabang ilmu kesehatan masyarakat yang berkaitan dengan semua aspek dari alam dan lingkungan yang dapat mempengaruhi kesehatan manusia. Kesehatan lingkungan didefinisi-kan oleh World Health Organization sebagai: aspek-aspek kesehatan manusia dan penyakit yang disebabkan oleh faktor-faktor dalam lingkungan. Hal 
ini juga mencakup pada teori dan praktek dalam menilai dan mengendalikan faktor-faktor dalam lingkungan yang dapat berpotensi mempengaruhi kesehatan. Kesehatan lingkungan mencakup efek patologis langsung bahan kimia, radiasi dan beberapa agen biologis, dan dampak (sering tidak langsung) di bidang kesehatan dan kesejahteraan fisik yang luas, psikologis, sosial dan estetika lingkungan termasuk perumahan, pembangunan perkotaan, penggunaan lahan dan transportasi. (Pirenaningtyas, 2007)

Kontribusi lingkungan dalam mewujudkan derajat kesehatan merupakan hal yang essensial di samping masalah perilaku masyarakat, pelayanan kesehatan dan faktor keturunan. Lingkungan memberikan kontribusi terbesar terhadap timbulnya masalah kesehatan masyarakat. (Pirenaningtyas, 2007)

Dalam bidang kesehatan masyarakat - Manajemen kesehatan adalah suatu kegiatan atau suatu seni untuk mengatur para petugas kesehatan dan nonpetugas kesehatan guna meningkatkan kesehatan masyarakat melalui program kesehatan." Dengan kata lain manajemen kesehatan masyarakat adalah penerapan manajemen umum dalam sistem pelayanan kesehatan masyarakat sehingga yang menjadi objek dan sasaran manajemen adalah sistem pelayanan kesehatan masyarakat. (Notoatmodjo, 2003).

Pengelolaan lingkungan termasuk pencegahan, penanggulangan kerusakan, pencemaran, dan pemulihan kualitas lingkungan. Hal tersebut telah menuntut dikembangkannya berbagai perangkat kebijakan dan program kegiatan yang didukung oleh sistem pendukung pengelolaan lingkungan lainnya. Sistem tersebut mencakup kemantapan kelembagaan, sumber daya manusia, dan kemitraan lingkungan disamping itu perangkat hukum dan perundangan, informasi serta pendanaan. Sifat keterkaitan (interdependensi) dan keseluruhan (holistik) dari esensi lingkungan telah membawa konsekuensi bahwa pengelolaan lingkungan, termasuk sistem pendukungnya tidak dapat berdiri sendiri, akan tetapi terintegrasikan dengan seluruh pelaksanaan pembangunan sektor dan daerah.

Sistem sanitasi juga memiliki permasalahan dan kendala tersendiri. Secara konsep, sistem sanitasi yang diterapkan di perkotaan seharusnya terpadu, komunal atau terpusat, jadi limbah dan saluran air kotor dapat diolah dengan teratur. Saluran-saluran yang membentuk jaringan sanitasi harus diarahkan pada kawasan pengolahan tersendiri, yaitu IPAL (Instalasi Pengolahan Air limbah). Melalui IPAL, warga kota bisa merasa nyaman karena tak perlu lagi membuang air kotor secara sembarangan. IPAL ini tidak hanya diperuntukkan bagi limbah rumah tangga, tetapi juga bagi sentra industri-industri, baik kecil atau besar.

Berdasarkan data Susenas, untuk fasilitas sanitasi, pencapaian Indonesia sempat meningkat tinggi dari tahun 1992 (30,9\%) sampai dengan tahun 1998 (64,9\%), dimana dalam 
enam tahun terjadi peningkatan sebanyak tiga kali lipat. Walaupun demikian, sejak tahun 1998 pertumbuhan akses ini melambat, bahkan sempat menurun di tahun 2000 (62,7\%) dan $2002(63,5 \%)$ karena tingkat pertumbuhannya tidak sebanding dengan tingkat pertumbuhan penduduk. Data terakhir untuk tahun 2004, proporsi rumah tangga yang memiliki akses pada fasilitas sanitasi yang layak, artinya menggunakan tangki septic atau lubang sebagai tempat pembuangan akhir mencapai dua pertiga dari seluruh rumah tangga di Indonesia $(67,1 \%)$.

Dari data di atas, tampaknya akses masyarakat pada fasilitas sanitasi yang layak cukup tinggi, sayangnya tingkat aksesibilitas ini tidak memperhitungkan kepemilikian atau tingkat penggunaan jamban itu sendiri. Padahal, menurut definisi dari UN-HABITAT, jamban yang layak sebaiknya digunakan oleh jumlah orang yang terbatas. Data tersebut juga belum menjelaskan kualitas jamban, apakah berfungsi dengan baik, apakah sesuai dengan peruntukannya, dan apakah sesuai dengan standar kesehatan maupun teknis yang telah ditetapkan. Maka dari itu pentingnya manajemen dalam penerapan sanitasi lingkungan.

\section{METODE}

tentang konsep manajemen kesehatan lingkungan perkotaan dengan pendekatan rasionalisme dan empirisme. Untuk mencapai tujuan dilakukan 3 tahapan analisa yaitu, pengidentifikasian faktor-faktor yang mempengaruhi kesehatan lingkungan dengan analisis deskriptif. Variabel yang diolah dengan menggunakan analisa deskriptif adalah kepadatan penduduk, pertumbuhan penduduk, karakter perumahan, kegiatan sosial, fasilitas pelayanan kota, kegiatan usaha, fasilitas perdagangan dan industri, jangkauan pelayanan ekonomi, pembangunan perumahan, pemanfaatan lahan, harga lahan, ukuran kota, jarak fisik ke kota induk, fasilitas perangkutan, jalan, dan utilitas. Setelah menggunakan analisa deskriptif kemudian digunakan metode delphi. Metode Delphi dipilih untuk menentukan faktor-faktor utama hasil opini para stakeholder. Analisa ke dua adalah menilai kinerja faktor-faktor tersebut dengan servis quality skala likert. Servqual digunakan untuk mengukur kinerja faktor-faktor yang berpengaruh untuk pengembangan kota baru, yaitu dengan membandingkan kinerja atau hasil yang dirasakan dengan harapan masyarakat atau penghuni perkotaan, sedangkan untuk bobot penilaian dengan skala likert. Dan analisa ke tiga adalah perumusan manajemen kesehatan lingkungan dengan menggunakan analisa triangulasi.

\section{PEMBAHASAN}

\section{Manajemen Kesehatan Lingkungan}

Secara etimologis kata manajemen berasal dari bahasa Perancis Kuno ménagement, yang berarti seni melaksanakan dan mengatur. Sedangkan secara terminologis para pakar mendefinisikan manajemen secara beragam, diantaranya: 
1. Ricky W. Griffin mendefinisikan manajemen sebagai sebuah proses perencanaan, pengorganisasian, pengkoordinasian, dan pengontrolan sumber daya untuk mencapai sasaran secara efektif dan efesien.

2. Manajemen adalah Suatu Proses dalam rangka mencapai tujuan dengan bekerja bersama melalui orang-orang dan sumber daya organisasi lainnya.

3. Follet yang dikutip oleh Wijayanti (2008: 1) mengartikan manajemen sebagai seni dalam menyelesaikan pekerjaan melalui orang lain.

4. Menurut Stoner yang dikutip oleh Wijayanti (2008: 1) manajemen adalah proses perencanaan, pengorganisasian, pengarahan, dan pengawasan usaha-usaha para anggota organisasi dan penggunaan sumber daya-sumber daya manusia organisasi lainnya agar mencapai tujuan organisasi yang telah ditetapkan

\section{Kesehatan Lingkungan}

Definisi kesehatan lingkungan menurut beberapa pendapat :

1) $\mathrm{WHO}$

Kesehatan lingkungan merupakan terwujudnya keseimbangan ekologis antara manusia dan lingkungan harus ada, agar masyarakat menjadi sehat dan sejahtera.

2) Soekidjo Notoadmojo

kesehatan lingkungan adalah suatu kondisi atau keadaan lingkungan yang optimum sehingga berpengaruh positif terhadap terwujudnya status kesehatan yang optimum pula

3) Mooler (1992)

kesehatan lingkungan adalah bagian dari kesehatan masyarakat yang memberi pengertian pada penilaian, pemahaman, dan pengendalian dampak pada manusia pada lingkungan dan dampak lingkungan pada manusia.

4) Menurut HAKLI ( himpunan Ahli Kesehatan Lingkungan Indonesia)

Kesehatan lingkungan adalah suatu kondisi lingkungan yang mampu menopang keseimbangan ekologi yang dinamis antara manusia dan lingkungannya untuk mendukung tercapainya kualitas hidup manusia yang sehat dan bahagia

5) Undang-undang Nomor 23 tahun 1992 pasal 22

a. Kesehatan lingkungan diselenggarakan untuk mewujudkan kualitas lingkungan yang sehat.

b. Kesehatan lingkungan diselenggarakan ditempat umum, lingkungan pemukiman, lingkungan kerja, angkutan umum dan lingkungan lainnya 
c. Kesehatan lingkungan meliputi penyehatan air dan udara, pengamanan limbah padat, limbah cair, limbah gas, radiasi dan kebisingan pengendalian vector penyakit, dan penyehatan atau pengamanan lainnya.

d. Setiap tempat atau sarana pelayanan umum wajib memelihara dan meningkatkan lingkungan yang sehat sesuai dengan standard an persyaratan.

e. Ketentuan mengenai penyelengaraan kesehatan lingkungan sebagaimana dimaksud diatas ditetapkan dengan peraturan pemerintah.

\section{Manajemen Kesehatan Lingkungan}

Dari kedua definisi tersebut antara manajemen dan kesehatan lingkungan maka dapat ditari sebuah kesimpulan manajemen kesehatan lingkungan adalah suatu seni yang melaksanakan dan mengatur system dari bagian kesehatan masyarakat untuk menopang keseimbangan ekologis antara manusia dan lingkungannya (biotic dan abiotik) guna tercapainya kualitas hidup manusia yang sehat dan bahagia

\section{FUNGSI MANAJEMEN KESEHATAN LINGKUNGAN}

\section{Fungsi Perencanaan}

Fungsi perencanaan lingkungan adalah fungsi terpenting dalam manajemen kesehatan lingkungan, oleh karena itu fungsi ini akan menentukan fungsi-fungsi manajemen lainnya. Fungsi perencanaan lingkungan merupakan landasan dasar dari fungsi manajemen kesehatan lingkungan secara keseluruhan. Tanpa ada fungsi perencanaan tidak mungkin fungsi manajemen lainnya akan dapat dilaksanakan dengan baik. Perencanaan manajerial akan memberikan pola pandang secara menyeluruh terhadap semua pekerjaan yang akan dijalankan, siapa yang akan melakukan dan kapan akan dilakukan. Perencanaan merupakan tuntunan terhadap proses pencapaian tujuan secara efisien dan efektif.

Perencanaan manajerial terdiri dari dua bagian utama yaitu perumusan strategi dan penerapan strategi. Pada fase perumusan strategi ditetapkan tujuan dan kebijaksanaan umum organisasi. Di sini dibutuhkan keterampilan manajerial yang bersifat konseptual. Untuk fase penerapan strategi ditentukan upaya pencapaian tujuan. Dalam hal ini dibutuhkan keterampilan manajerial yang bersifat teknis. Perumusan strategi biasanya dikerjakan oleh pimpinan puncak suatu organisasi sedangkan implementasinya dikerjakan sepenuhnya oleh para manajer pelaksana dikordinir oleh manajer tingkat menenga.

\section{Fungsi pengorganisasian}

menjelaskan pengorganisasian merupakan suatu proses untuk merancang struktur formal, mengelompokkan dan mengatur serta membagi tugas-tugas atau pekerjaan di antara para anggota organisasi, agar tujuan organisasi dapat dicapai dengan efisien. 
Pengorganisasian merupakan proses penyusunan struktur organisasi yang sesuai dengan tujuan organisasi, sumber daya-sumber daya yang dimilikinya, dan lingkungan yang melingkupinya.

\section{Fungsi penggerakan dan Pelaksanaan}

Menurut Nawawi (2000) pelaksanaan atau penggerakan (actuating) yang dilakukan setelah organisasi memiliki perencanaan dan melakukan pengorganisasian dengan memiliki struktur organisasi termasuk tersedianya personil sebagai pelaksana sesuai dengan kebutuhan unit atau satuan kerja yang dibentuk. Di antara kegiatan pelaksanaan adalah melakukan pengarahan, bimbingan dan komunikasi termasuk koordinasi.

Koordinasi sebagai proses pengintegrasian tujuan dan kegiatan pada satuan kerja yang terpisah suatu organisasi untuk mencapai tujuan organisasi secara efisien. Tanpa koordinasi, individu dan departemen-departemen akan kehilangan pegangan atas peranan mereka dalam organisasi. Mereka mulai mengejar kepentingan diri sendiri yang sering merugikan pencapaian tujuan organisasi secara keseluruhan

\section{Fungsi pengawasan dan pengendalian}

upaya penerapan standar pelaksanaan, merancang sistem informasi umpan balik, membandingkan kegiatan nyata dengan standar yang ada, menentukan dan mengukur penyimpangan-penyimpangan serta mengambil tindakan koreksi yang diperlukan untuk menjamin bahwa usaha atau kegiatan telah dilaksanakan secara baik dalam mencapai tujuan (Handoko, 1984).

\section{Konsep dasar Peran manajemen Kesehatan Lingkungan}

Konsep dasar dan prinsip-prinsip pengelolaan lingkungan tidak dapat dilakukan tanpa pembahasan yang kritis dan holistik tentang lingkungan. Konsep dan penjelasan tentang lingkungan cenderung semakin kompleks dan dinamik, berkembang dari konsepsi tradisional yang cenderung sempit, yang mengartikan lingkungan sekedar sebagai suatu kesatuan ekosistem alam menjadi keterkaitan yang integral antara manusia dan sistem lingkungan.

Untuk mengkaji lingkungan harus dilihat secara komfrehensif sebagai satu kesatuan yang saling berhubungan (interaction) dan saling ketergantungan (interdependency). Arti dan cakupan yang terkandung dalam kajian lingkungan menekankan pada integrasi dinamik dan kompleks antara lingkungan fisik-alami dengan manusia dan sistem sosialnya. Hal ini mempunyai konsekuensi, bahwa memahami lingkungan harus secara holistik tidak terbatas pada aspek fisik-alami semata, tetapi juga aspek sosial, ekonomi, budaya, serta, politik 
masyarakat dalam suatu sistem waktu dan tempat yang khusus. Saat ini banyak dipakai konsepsi $\mathrm{ABC}$ untukmenjelaskan tiga komponen lingkungan yang tak terpisahkan yakni "Abiotik", "Biotik", serta "Culture".

Suatu wilayah akan selalu terjadi hubungan (interaction) antara mahluk hidup dengan lingkungan. Lingkungan memberikan materi dan energi bagi kehidupan mahluk hidup, maka mahluk hidup akan tumbuh dan berkembang optimal. Sebaliknya bila tidak sesuai dengan kebutuhan energi maka akan melakukan adaptasi, jika tidak mampu akan mutasi/ pindah atau musnah/ mati.

Pengelolaan lingkungan mempunyai dua dimensi yaitu "keterpaduan" dan "konflik". Idealnya, berbagai instrumen pengelolaan lingkungan dapat dirumuskan secara terpadu sehingga dapat mengakomodasi berbagai kelompok kepentingan. Dalam prakteknya, pengelolaan lingkungan tidak dapat dilepaskan dari konflik. Oleh karenanya para pengelola lingkungan harus mempunyai kapasitas untuk mengelola konflik dari berbagai kepentingan yang saling bertentangan.

\section{MACAM-MACAM MANAJEMEN KESEHATAN LINGKUNGAN}

\section{Total Quality Enviromental Management (TQEM)}

Pengelolaan kualitas lingkungan menyeluruh (PKLM) merupakan konsep baru, tetapi semakin lamamenjadi praktik yang penting dalam manajemen industry. PKLM dihasilkan melalui penerapan ide-ide dan Tehnik Kualitas menyeluruh (total quality management) ke dalam manajemen lingkungan, yang dipelopori oleh Global Enviromental Mangement intiative (GEMI), suatu organisasi yang dibentuk oleh perusahaan-perusahaan Amerika yang berhasil dalam manajemen lingkungan.

PKLM berkembang dari kesadaran bahwa terdapat hubungan timbval balik antara manajemen lingkungan dengan manajemen mutu. PKLM telah membantu mengembangkan sejumlah inisatif untuk menggabungkan semua masaalah lingkungan disemua tingkat proses pengambilan keputusan. Inisiatif-inisiatif ini termasuk pengurusan produk, keamanan lingkungan dan inisiatif kesehatan, system manajemen lingkungan dan standar ISO 14000. Semua aspek ini serta inisiatif inovatif lainnya berkembang bersama-sama dengan konsep PKLM.

PKLM merupakan konsep yang mengawinkan ide dan Teknik Manajemen Kualitas menyeluruh (total quality management) dengan manajemen lingkungan. Seperti halnya MKM, PKLM juga bertujuan untuk memenuhi kepuasan pelanggan, melakukan peningkatan secara terus menerus dan pengukuran yang setepat-tepatnya. PKLM juga memerlukan kemudahan untuk mendapatkan informasi dan komunikasi yang sangat penting, khususnya 
yang memberikan gambaran mengenai kinerja manajemen lingkungan. Pada akhirnya, PKLM tetaplah merupakan suatu tekhnik manajemen yang membawa perusahaan kea rah tujuan bersih lingkungan dan implementasi praktik-praktik perusahaan yang lebih sukses.

Beberapa penelitian menyebutkan PKLM merupakan suatu pendekatan untuk meningkatkan kualitas lingkungan proses dan produk secara terus menerus melalui partisipasi semua tingkat dan fungsi dalam suatu organisasi. PKLM (seperti juga MKM) bertujuan mengikuti atau mungkin melampaui perubahan keinginan/harapan pelanggan akan suatu produk pencarian terus menerus untuk meningkatkan kesempatan tercapainya tujuan tersebut.

\section{Countinous Quality Improvement (CQI)}

Total quality dimulai dengan menyadari bahwa kita tidak akan pernah sebaik yang kita harapkan. Peningkatan secara terus menerus berdasarkan data dan pengukuran merupakan dasar daritotal quality. Hal yang sama juga dilakukan dalam pencapaian performa lingkungan suatu organisasi yang lebih baik secara terus menerus sehingga memberikan kepuasan bagi pelanggannya.

Untuk organisasi atau perusahaan yang bergerak dibidang manufuktur, pemenuhan pengelolaan lingkungan sesuai dengan standar internasional (ISO 14001) bukan merupakan hal baru. Hal ini disadari dilakukan di tingkat internasional yang menuntun dipenuhinya standar internasional yang berlaku didunia. Dengan dipenuhinya unsure-unsur dalam ISO 14001 terdapat kepastian bahwa perusahaan mempunyai kualitas pengelolaan lingkungan yang baik.

\section{PENDEKATAN-PENDEKATAN MANAJEMEN KESEHATAN LINGKUNGAN}

1. Penguatan Lembaga

a. Penguatan Kelembagaan Pengelolaan Air Minum dan Sanitasi Perdesaan Berbasis Masyarakat.

b. Penguatan Peran Kader AMPL dalam Pemutakhiran Data Air Minum Dan Sanitasi Perdesaan dan Prioritasi Program Air Minum Dan Sanitasi Perdesaan di Tingkat Kecamatan.

c. Peningkatan Kinerja BPSPAMS

\section{Pengelolaan Data}

a. Pengelolaan Data/Informasi Sistem Penyediaan Air Minum dan Sanitasi (SPAMS) Perdesaan Terpadu

b. Penguatan Peran Kader AMPL dalam Pemutakhiran Data Air Minum Dan Sanitasi Perdesaan dan Prioritasi Program Air Minum Dan Sanitasi Perdesaan di Tingkat Kecamatan. 
3. Penguatan dukungan terhadap pemerintah Daerah dengan melalui :

a. Dukungan kerangka kebijakan regulasi

b. Pengintegrasian Perencanaan Air Minum dan Sanitasi tingkat desa dalam Perencanaan dan Penganggaran Daerah

c. Membangun kerjasama/kolaborasi

4. Mekanisme Insentif untuk Desa/Kelurahan dan Kabupaten/Kota

Insentif desa/kelurahan dan kabupaten/kota dilaksanakan sebagai dukungan keberlanjutan pengembangan jangkauan dan kualitas pelayanan SPAM perdesaan.Insentif diberikan kepada desa/kelurahan atau kabupaten/kota yang telah melaksanakan Pamsimas dengan kinerja baik namun masih memiliki.

\section{HAMBATAN-HAMBATAN PENERAPAN MANAJEMEN KESEHATAN LINGKUNGAN}

Tantangan utama dalam pengelolaan kegiatan penyediaan air minum dan sanitasi perdesaan antara lain Belum tersedianya lembaga yang khusus menangani pengelolaan air minum dan sanitasi perdesaan sebagaimana PDAM di perkotaan, Belum tersedianya sistem data/informasi air minum dan sanitasi perdesaan, untuk menjadi bagian dari sistem informasi kinerja penyelenggaraan pembangunan daerah, yang andal sebagai basis pengambilan keputusan program dan anggaran pembangunan air minum dan sanitasi perdesaan, Belum memadainya dukungan program dan anggaran daerah yang memberikan fokus pada peningkatan kinerja pelayanan air minum dan sanitasi perdesaan, Belum memadainya investasi bagi sistem penyediaan air minum dan sanitasi perdesaan; pendanaan masih bertumpu pada anggaran Pemerintah, alokasi APBD untuk pembangunan air minum dan sanitasi masih rendah, dan belum dimanfaatkannya potensi pendanaan dari swasta dan masyarakat.

\section{KESIMPULAN}

Manajemen Kesehatan Lingkungan adalah suatu seni yang melaksanakan dan mengatur system dari bagian kesehatan masyarakat untuk menopang keseimbangan ekologis antara manusia dan lingkungannya (biotic dan abiotik) guna tercapainya kualitas hidup manusia yang sehat dan bahagia. Peran manajemen dalam kesehatan lingkungan adalah Pengelolaan lingkungan mempunyai dua dimensi yaitu "keterpaduan" dan "konflik". Idealnya, berbagai instrumen pengelolaan lingkungan dapat dirumuskan secara terpadu sehingga dapat mengakomodasi berbagai kelompok kepentingan. Dalam prakteknya, pengelolaan lingkungan tidak dapat dilepaskan dari konflik. Oleh karenanya para pengelola 
lingkungan harus mempunyai kapasitas untuk mengelola konflik dari berbagai kepentingan yang saling bertentangan.

Manajemen kesehatan lingkungan antara lain Total Quality Enviromental Management (TQEM), Countinous Quality Improvement (CQI), Pendekatan Manajeme Kesehatan Lingkungan Penguatan lembaga, Proses pengolahan data, Penguatan dukungan terhadap pemerintah Daerah, Hambatan-hambatan penerapan manajemen kesehatan lingkungan. Belum tersedianya lembaga yang khusus menangani pengelolaan air minum dan sanitasi perdesaan sebagaimana PDAM di perkotaan. Belum tersedianya sistem data/informasi air minum dan sanitasi perdesaan, untuk menjadi bagian dari sistem informasi kinerja penyelenggaraan pembangunan daerah, yang andal sebagai basis pengambilan keputusan program dan anggaran pembangunan air minum dan sanitasi perdesaan. Belum memadainya dukungan program dan anggaran daerah yang memberikan fokus pada peningkatan kinerja pelayanan air minum dan sanitasi perdesaan. Belum memadainya investasi bagi sistem penyediaan air minum dan sanitasi perdesaan; pendanaan masih bertumpu pada anggaran Pemerintah, alokasi APBD untuk pembangunan air minum dan sanitasi masih rendah, dan belum dimanfaatkannya potensi pendanaan dari swasta dan masyarakat.

\section{REFERENCE}

Adisasmito W. 2007. System manajemen lingkungan rumah sakit. Jakarta. Rajawali pers http://blogbintang.files.wordpress.com/2012/09/blogbintangmakalah-kesehatan-

lingkungan.pdf diakses pada tanggal 27 Oktober 2014

http://digilib.its.ac.id/public/ITS-Undergraduate-12362-Chapter1.pdf diakses pada tanggal 27

Oktober 2014

http://www.indonesian-publichealth.com/2014/04/pengertian-manajemen-

kesehatan.html diakses pada tanggal 27 Oktober 2014

http://eprints.uny.ac.id/8527/2/BAB\%201\%20-\%2007401241024.pdf diakses pada tanggal 27 oktober 2014

http://www.ampl.or.id/digilib/read/Permasalahan-Sanitasi/4994diakses pada tanggal 27 oktober 2014

http://blogseobrilliant.blogspot.com/2014/03/pengertian-dan-fungsi-manajemen.html diakses pada tanggal 31 oktober 2014

http://ielmy.wordpress.com/other/definisi-manajemen/ diakses pada tanggal 31 oktober 2014 http://eprints.uny.ac.id/9870/2/BAB\%202\%20-\%2006209241002.pdf diakses pada tanggal 31 oktober 2014

http://www.indonesian-publichealth.com/2013/09/fungsi-manajemen.html diakses pada tanggal 31 oktober 2014

http://eprints.undip.ac.id/18795/1/SUTRISNO.pdf diakses pada tanggal 31 oktober 2014 http://repository.usu.ac.id/bitstream/123456789/4723/5/Chapter\%20II.pdf diakses pada tanggal 31 oktober 2014 
http://www.ampl.or.id/pdf/pedoman/pamsimas/P2\%20FINAL\%20Pedoman\%20Pelaksanaan \%20Program\%20Pamsimas\%202013\%20_rev\%2013-92013 ok.pdf diakses pada tanggal 31 oktober 2014

http://alfi-syahrinnur.blogspot.co.id/2014/12/contoh-makalah-manajemen-lingkungan.html diakses pada tanggal 14 Pebruari 2018

Munimjaya Gde. 2011. Manajemen Kesehatan. Jakarta. Penerbit Buku Kedokteran.

Mahrus, A., Wicaksono, H. B., Cholil, H., \& Wiwoho, M. S. (2017). Mapping of Biomass

Production of Land Damage Assessment to Reduce Environmental Changes In East Java Probolinggo. In MATEC Web of Conferences (Vol. 138, p. 9004). EDP Sciences.

Suyono n Chandra B. 2010. Ilmu Kesehatan masyarakat dalam Konteks Kesehatan Lingkungan. Jakarta. Penerbit Buku Kedokteran. 